\title{
WIKIPEDIA
}

\section{Xà bông Cô Ba}

Bách khoa toàn thư mở Wikipedia

Xà bông Cô Ba là một nhãn hiệu xà bông lâu năm tại Việt Nam thuộc sở hữu của công ty An Dương Thảo Điền.

\section{Bối cảnh}

Xà phòng được người Pháp du nhập vào Việt Nam từ đầu thế kỷ 20.[1] Lúc bấy giờ, hãng xà phòng chiếm lĩnh thị trường Việt Nam là thương hiệu xà bông Marseille do người Pháp sản xuất. [2] Có rất ít cơ sở sản xuất nhỏ lẻ chiếm thị phần không đáng kể, phần lớn sản xuất xà bông để rửa tay hay giặt giũ cho giới lao động. Lúc bấy giờ người Việt vẫn chưa có hãng xà bông tắm gội riêng. [3] Năm 1928, doanh nhân Trương Văn Bền thành lập xưởng chế dầu ở Chợ Lớn sản xuất các loại dầu ăn, dầu công nghiệp. [4]

Năm 1865, một cuộc thi hoa hậu được tổ chức tại Sài Gòn, cho phép nhiều cô gái đến từ miền Nam tham dự. Tại cuộc thi này, cô Ba Thiệu con ông Thông Chánh, quê Trà Vinh đăng quang. Hình ảnh của cô Ba sau này được hiệu buôn xà bông của ông Trương Văn Bền sử dụng làm người mẫu trên các

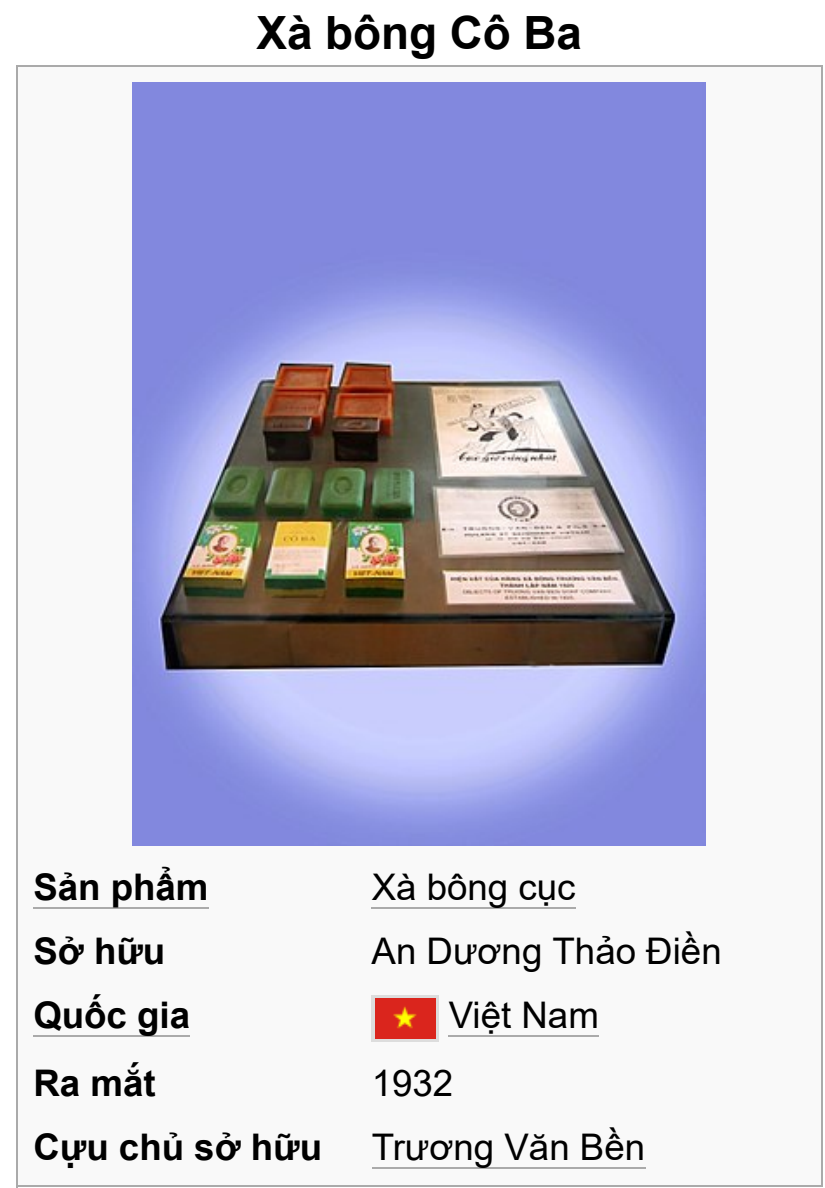
sản phẩm bán ra thị trường. Cũng có một số tài liệu khác cho rằng hình người phụ nữ trên miếng xà bông không phải là cô Ba Thiệu mà là cô Ba có tên Trà, vợ của ông Trương Văn Bền. [5]

\section{Lịch sử}

Xà bông Cô Ba là một nhãn hiệu xà bông do ông Trương Văn Bền thành lập năm 1932. [6][7] Đây là nhãn hiệu xà phòng tắm gội đầu tiên của người Việt Nam. ${ }^{[8]}$ Theo lời kể của Trương Văn Bền, sở dĩ ông lấy tên Việt đặt cho mặt hàng của mình là do chịu ảnh hưởng từ vụ người Pháp xử tử các thành viên Việt Nam Quốc dân Đảng. [9] Hãng xà bông Cô Ba có trụ sở cạnh nhà máy ép dầu dừa mà Trương Văn Bền xây dựng trước đó. [6] Thời gian đầu, thương hiệu chỉ phân phối ở Sài Gòn, Chợ Lớn, Gia Định, Biên Hòa; việc phân phối đến các địa phương khác phụ thuộc vào những

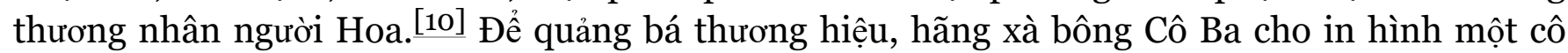
gái và tận dụng chủ nghĩa dân tộc Việt Nam để thu hút người tiêu dùng. ${ }^{[4][10]}$ Ngoài Việt Nam, xà bông Cô Ba được xuất khẩu sang Lào, Campuchia, Hồng Kông và châu Phi. ${ }^{[11]}$ Sau đó, hãng dùng các đại lý để phân phối sản phẩm đến các tỉnh. Dưới thời Đệ nhất Cộng hòa, hãng của Trương Văn Bền chi gần 500.000 đồng thuê một đoàn võ thuật theo vừa biểu diễn, vừa quảng bá sản phẩm. ${ }^{[12]}$ Trong thập niên 1960, trước sự đổ bộ của hàng ngoại nhập, đặc biệt là các mặt hàng từ Hoa Kỳ, xà bông Cô Ba bị mất thị phần. [7] Sau sự kiện 30 tháng 4 năm 1975, xà bông Cô Ba bị quốc hữu hóa, ${ }^{[13]}$ hợp nhất vào Nhà máy công tư hợp doanh xà bông Việt Nam. ${ }^{[2]}$ Nhiều nguyên liệu để làm xà bông cũng không còn được nhập, thiếu nguyên liệu để gia công sản phẩm theo quy 
trình hiện đại.[13] Năm 1995, Nhà máy đổi tên thành Công ty Phương Đông thuộc Bộ Công nghiệp. ${ }^{[14]}$ Cuối những năm 2010, công ty An Dương Thảo Điền bỏ 200 tỷ đồng để sở hữu $30,88 \%$ cổ phần công ty. $[15]$

\section{Tham khảo}

1. ^ Đỗ Phấn (8 tháng 3 năm 2015). "Xà phòng biên niên". Sài Gòn Giải Phóng. Bản gốc lưu trữ ngày 12 tháng 1 năm 2021. Truy cập ngày 8 tháng 8 năm 2020 .

2. $\wedge a b$ Trần Chánh Nghĩa (26 tháng 6 năm 2018). "Bài 1: Chuyện chưa nói hết về huyền thoại xà bông cô Ba". Phụ Nữ. Bản gốc lưu trữ ngày 12 tháng 1 năm 2021. Truy cập ngày 8 tháng 8 năm 2020 .

3. ^ "Bí quyết xà bông Cô Ba đánh bại thương hiệu Pháp". VietNamNet. 12 tháng 6 năm 2016. Bản gốc lưu trữ ngày 12 tháng 1 năm 2021. Truy cập ngày 8 tháng 8 năm 2020.

4. $\wedge$ a $b$ Nguyễn Đức Hiệp (21 tháng 2 năm 2014). "Kỹ nghệ khiến xà bông Việt từng "bóp chết" mỹ phẩm Pháp?". Pháp Luật. Bản gốc lưu trữ ngày 12 tháng 1 năm 2021. Truy cập ngày 8 tháng 8 năm 2020.

5. ^ Sơn Hòa (7 tháng 8 năm 2016). "Đệ nhất mỹ nhân đầu tiên của Sài Gòn và cái kết bi thảm". VnExpress. Bản gốc lưu trữ ngày 12 tháng 1 năm 2021. Truy cập ngày 8 tháng 8 năm 2020.

6. ^ a b Đặng, Phong (2002). Lịch sử kinh tế Việ̂ Nam, 1945-2000. Nhà xuất bản khoa học xã hội. tr. 56.

7. ^ $\boldsymbol{a} \boldsymbol{b}$ "Xà bông Cô $\mathrm{Ba}$ - Hương thơm từ ký ức". Đài Truyền hình Việt Nam. 15 tháng 8 năm 2019. Bản gốc lưu trữ ngày 12 tháng 1 năm 2021. Truy cập ngày 8 tháng 8 năm 2020.

8. ^ Phạm Minh, Chính; Vương Quân, Hoàng (15 tháng 6 năm 2009). Kinh tế Việt Nam: Thăng trầm và đột phá. 2. Nhà xuất bản Chính trị quốc gia - Sự thật. tr. 38. Lưu trũ bản gốc ngày 12 tháng 1 năm 2021. Truy cập ngày 8 tháng 8 năm 2020. Chú thích có tham số trống không rõ: | khác= (trợ giúp)
9. ^ Phạm Trường Giang (12 tháng 6 năm 2016). "Xà bông Cô Ba đánh bay hàng ngoại”. Pháp Luật. Bản gốc lưu trữ ngày 12 tháng 1 năm 2021. Truy cập ngày 10 tháng 8 năm 2020.

10. ^ $\boldsymbol{a} \boldsymbol{b}$ Hoàng Thư (7 tháng 5 năm 2020). "Huyền thoại trăm tuổi mang tên Cô Ba "ở ẩn" nơi nào?". Pháp Luật. Bản gốc lưu trữ ngày 12 tháng 1 năm 2021. Truy cập ngày 8 tháng 8 năm 2020.

11. ^ Đình Du (6 tháng 11 năm 2018). "Xà bông Cô Ba: Sự trở lại của huyền thoại”. Tiền Phong. Bản gốc lưu trữ ngày 12 tháng 1 năm 2021. Truy cập ngày 10 tháng 8 năm 2020.

12. ^ Lê Minh Quốc (13 tháng 4 năm 2014). "Người vinh danh xà bông Việt Nam". Thanh Niên. Bản gốc lưu trữ ngày 12 tháng 1 năm 2021. Truy cập ngày 8 tháng 8 năm 2020.

13. ^ $\boldsymbol{a} \boldsymbol{b}$ Osin Huy Đức (2012). Bên thắng cuộc: Quyền bính. 2. Amazon Digital Services LLC - Kdp Print Us. ISBN 9781629884738. Lưu trữ bản gốc ngày 12 tháng 1 năm 2021 . Truy cập ngày 8 tháng 8 năm 2020. Chú thích có tham số trống không rõ: | khác= (trợ giúp)

14. ^ Nhật Khánh (9 tháng 6 năm 2019). "Ông chủ mới khó khăn, xà bông Cô Ba 'hồi sinh' bất thành". VTC News. Bản gốc lưu trữ ngày 12 tháng 1 năm 2021 . Truy cập ngày 8 tháng 8 năm 2020.

15. ^ Phương Đông (30 tháng 4 năm 2019). "An Dương Thảo Điền có thể tìm đối tác khôi phục 'Xà bông Cô Ba'". VnExpress. Bản gốc lưu trữ ngày 12 tháng 1 năm 2021. Truy cập ngày 8 tháng 8 năm 2020.

Lấy từ “https://vi.wikipedia.org/w/index.php?title=Xà_bông_Cô_Ba\&oldid=65066224" 
